\title{
Prevalence, characteristics, and predictors of pre-diabetes in Indonesia
}

\author{
Pradana Soewondo, Laurentius A. Pramono \\ Department of Internal Medicine, Faculty of Medicine, Universitas Indonesia, Jakarta, Indonesia
}

\begin{abstract}
Abstrak
Latar belakang: Prediabetes merupakan kondisi kadar glukosa darah di atas normal, tapi belum memenuhi standar diagnosis diabetes. Kondisi ini merupakan tahap kritis di mana bila tidak dilakukan perubahan gaya hidup dan pengobatan yang adekuat, subjek dapat jatuh pada diagnosis diabetes. Penelitian ini bertujuan memperoleh prevalensi prediabetes di Indonesia dan faktor-faktor prediksinya.
\end{abstract}

Metode: Penelitian ini dilakukan oleh Divisi Metabolik Endokrin Departemen Ilmu Penyakit Dalam FKUI/RSCM dan Pusat Diabetes dan Lipid Jakarta dengan disain potong lintang, menggunakan data sekunder dari Survei Riset Kesehatan Dasar Indonesia tahun 2007. Total responden adalah 24417 subjek dari 33 provinsi di Indonesia. Analisis dilakukan terhadap karakteristik, uji korelasi, faktor-faktor prediksi, dan analisis ukuran dampak/efek.

Hasil: Prevalensi prediabetes di Indonesia diperoleh berdasarkan data TGT (toleransi glukosa terganggu) sebesar 10\%. Faktor-faktor prediksi prediabetes di Indonesia adalah jenis kelamin laki-laki, usia lanjut, status sosial ekonomi tinggi, tingkat pendidikan rendah, hipertensi, obesitas, obesitas sentral, dan kebiasaan merokok. Prioritas pencegahan diabetes dan prediabetes di Indonesia diarahkan pada target penurunan tekanan darah (Attributable Risk/AR 56.5\%), pengecilan lingkar pinggang (AR 47.3\%), dan berhenti merokok (AR 44.4\%).

Kesimpulan: Prevalensi prediabetes di Indonesia sangat besar (10\%) sehingga perlu dilakukan strategi pencegahan baik terhadap prediabetes maupun progresivitas prediabetes menjadi diabetes. Implementasi berbagai strategi itu dirangkum dan dijalankan melalui Indonesian Diabetes Prevention Program (IDPP). (Med J Indones 2011; 20:283-94)

\begin{abstract}
Background: Pre-diabetes is a state where glucose level higher than normal, but not satisfy the criteria for diabetes. This condition is very critical, so that if subject don't do lifestyle modification and pharmacology therapy, they could fall to diabetes. This research objective is to describe the prevalence and predictors of pre-diabetes in Indonesia.

Methods: A cross-sectional study was conducted by Metabolic Endocrinology Division, Department of Internal Medicine FMUI/RSCM and Jakarta Diabetes and Lipid Center using secondary data from National Health Survey 2007. Total respondents are 24417 subjects from 33 provinces in Indonesia. We analyze characteristics, correlation, predictors, and attributable risks for some predictors of pre-diabetes and diabetes.

Results: Prevalence of pre-diabetes (based on impaired glucose tolerance data) in Indonesia is $10 \%$. Predictors of pre-diabetes are male, old-age, high socio-economic status, low education level, hypertension, obesity, central obesity, and smoking. Priority for pre-diabetes and diabetes prevention in Indonesia directed to decrease blood pressure (Attributable Risk/AR 56.5\%), reduce waist circumference (AR 47.3\%), and stop smoking (AR 44.4\%).

Conclusion : Prevalence of pre-diabetes in Indonesia is high so that we need a prevention strategy for pre-diabetes and the development from pre-diabetes to diabetes. The implementation of those strategies is compiled in the Indonesian Diabetes Prevention Program.(Med J Indones 2011; 20:283-94)
\end{abstract}

Keywords: diabetes, Indonesian diabetes prevention program, pre-diabetes

According to the definition of the American Diabetes Association and US Department of Health and Human Services, " "pre-diabetes is a condition where blood glucose contain is above normal, but it does not measure up to the criteria of diabetes mellitus yet". Two conditions included in pre-diabetes are IGT (Impaired Glucose Tolerance) and IFG (Impaired Fasting Glucose). ${ }^{1,2}$ Standard value for pre-diabetes is blood glucose level of $100-125 \mathrm{mg} / \mathrm{dL}$ for fasting blood glucose (called IFG) or $140-199 \mathrm{mg} / \mathrm{dL}$ for blood glucose two hour post glucose load (called IGT), or both. ${ }^{2}$
According to the Consensus of Management and Prevention of Diabetes Mellitus Type- 2 in Indonesia, issued by Indonesian Society for Endocrinologist, ${ }^{3}$ "the upholding of IGT and IFG is established according to the standard diagnostic algorithm". To the patient with diabetes classic complain, if after two times test of the one-time blood glucose and fasting blood glucose, we get a doubtful results (above normal, but does not measure up to the criterion of diabetes), the patient will asked to carry out the load procedure of OGTT(Oral Glucose Tolerance Test). When the results of blood glucose two hour post glucose load is $140-199 \mathrm{mg} / \mathrm{dL}$, 
the patient will be included in the criteria of impaired glucose tolerance. ${ }^{3,4}$

Pre-diabetes is a global health problem, which is extremely important at this moment. The prevalence of pre-diabetes, in fact, even higher than the diabetes prevalence. The person, who develops pre-diabetes, is going to become diabetes in several months or year, if he/she goes untreated in an appropriate and adequate manner. ${ }^{2}$ Diabetes prevalence in the United States is 24.1 million people; while pre-diabetes is 57 million people (more than twice that of diabetes). ${ }^{2}$ According to National Health Survey, the prevalence of diabetes as well as impaired glucose tolerance on adults in Singapore, are $9 \%$ and $15 \%$ each. ${ }^{5}$

The results of the survey conducted on several urban diseases in Jakarta in 2006, showed that pre-diabetes prevalence was $24.91 \%{ }^{6}$ The figure consisted of Impaired Glucose Tolerance $17.90 \%$ and Impaired Fasting Glucose 7.01\%. ${ }^{6}$ Data of Basic Health Research, Ministry of Health Republic of Indonesia 2007, alluded that the prevalence of Impaired Glucose Tolerance on urban residents in Indonesia is $10.2 \%$. This figure exceeds the prevalence of total diabetes as big as $5.7 \%$. Three provinces with the highest IGT prevalence in Indonesia are West Papua, West Sulawesi and Sulawesi; each province got the percentage of $21.8 \%, 17.6 \%$ and $7.3 \%$.

Pre-diabetes is a serious condition. Anyone who carries pre-diabetes runs the big risk to be diagnosed with diabetes mellitus. The study made by Vegt et al. ${ }^{7}$ found out that prediabetes progressivity to be diabetes is $6-10 \%$ per year. For patients who carry both IGT and IFG, cumulative incidence in the period of 6 years is $65 \%$, compared with the person with normal blood glucose level.

Several studies made by, among others; AusDiab, Framingham, DREAM, and STOP-NIDDM, found out that the risks to be affected by cardio-vascular is twice that of pre-diabetes' (IGT and IFG) victims, compared to an individual with normal glucose level Coutinho discovered that IGT and IFG escalate the cardiovascular risk, each by $60 \%$ and $30 \%$. The similar is put forward by DECODE study, that found out that the cardiovascular risk higher on individuals with the increasing blood glucose contain, two hour post-glucose-load

According to the guidelines issued by European Society for Cardiology (ESC) and European Association for the Study of Diabetes (EASD) ${ }^{8}$ 2007, pre-diabetes is related to several conditions, they are : old age, obesity, central obesity, lack of physical activities, lack of fruits and vegetable consumption, family history and hypertension. According to Pre-diabetes Consensus issued by American College of Endocrinology (ACE) and American Association of Clinical Endocrinology $(\mathrm{AACE})^{2}$ in 2008, risk factors of diabetes and pre-diabetes are: family history, coroner heart disease, overweight and obesity, unhealthy life styles and hypertension. Any individuals who carried pre-diabetes (IGT or DPPT), run the higher risk of getting affected diabetes.

The lack of pre-diabetes guidance/consensus and the screening on diabetes creates the condition that makes pre-diabetes goes unknown and unwatched. ${ }^{9}$ For the purpose of screening of some predictive factors, several factors discovered in every country differs one each other, so that we cannot just generalize the data coming from other countries for the sake of the screening in Indonesia. Up to this moment, there is no study in Indonesia that investigates all sorts of predictive factors of pre-diabetes across the country and its relations with various demographic data.

This study is the first one of the kind conducted in Indonesia, aiming at finding out the relations between pre-diabetes and socio-demography of Indonesian society, along with their predictive factors, which are interrelated in more details. As a study material, the data is provided by Basic National Health Survey from Health Department RI 2008 can be an appropriate reference to investigate nation-widely the risk factors related to pre-diabetes. By knowing the predictive factors that reveal to us how pre-diabetes occur, we hopefully can strive for an appropriate and adequate prevention. Besides, we can also determine the needed screening data, in order to detect pre-diabetes early before it develops to become diabetes.

\section{METHODS}

This study use secondary data coming from Basic Health Research Survey, Ministry of Health Republic of Indonesia 2007, designed in a cross-sectional way. The study was conducted nation-wide throughout 33 Provinces across Indonesia, engaging 24417 respondents coming from urban subjects.

The population of this study included all adults above 18 years of age across Indonesia. The population engaged was the respondents who took part in the blood glucose contain examination, available on the Basic Health Survey, Health Department RI 2007. Samples required were all study subjects who passed the inclusion criteria and did not measure up to the exclusion criteria. Samples were excluded when the results were damaged and could not be analyzed and had incomplete data in the analyzed variables.

The arrangement for the blood glucose contain examination, was made by using OGTT (Oral glucose 
Tolerance Test). To establish diabetes diagnoses, we referred to WHO 1999 and American Diabetes Association 2003, which was already adapted by the Board of Directors of Indonesian Society for Endocrinologist that was: 2 hours post load glucose level of $140-199 \mathrm{mg} / \mathrm{dl}$.

It was stipulated that the criteria for socio-economical status was based on the expenditure, whereby the expenditure quintile 1 and 2 went to the category of low socio-economical status, while the expenditure in quintile 3,4 and 5 went to the category of high socioeconomical status. The criterion for education level was determined as follows: those who graduated from high-school up, were classified as high educational level, while those who were under-high-school, were classified as low educational level. As for the obesity criterion, we used the Asia Pacific Standard, which was: BMI (body mass index) $\geq 25 .{ }^{10}$ Central obesity was determined by waist circumference, using a fiberglass tape with the precision up to $0.1 \mathrm{~cm}$, on Asia Pacific Standard basis, that was: for men, waist circumference $\geq 90 \mathrm{~cm}$, and for women waist circumference $\geq 80$ $\mathrm{cm} .{ }^{11}$ Hypertension was determined by using blood pressure standard, on JNC VII basis was: the average blood pressure above $140 \mathrm{mmHg}$ for systolic and 90 $\mathrm{mmHg}$ for diastolic. ${ }^{12}$

Adequate physical activities included activities that needed physical exercises, whether it was a light, medium, or a heavy one, more that 150 minutes per week. Risky diet pattern was determined that the subject who consumed fruit and vegetables under 5 portions per day is classified as high risk. Meanwhile, the criterion for access to the health services was: access to the health service was classified as difficult if the radius to the nearest health service was farther than $1 \mathrm{~km}$ away or the duration was longer than 1 hour's walk. Smoking habit was classified as : smoking daily, smoking once in a while, ex-smoker and non- smoking.

Furthermore, the data obtained would be analyzed by using SPSS 13.0 program. The analysis was carried out in the Division of Metabolic Endocrinology, Department of Internal Medicine, FMUI/RSCM, and Jakarta Diabetes and Lipid Center from November 2009 to January 2010. The data analysis covered basic characteristics of study sample, relation between prediabetes with several risk factors, and predictors of pre-diabetes comes out from the multivariate analysis. In the framework of seeking for a complete picture of pre-diabetes in Indonesia, we also carried out a study of ecology and the measuring of its impacts/effects as a means to determine the priority of social health actions or an adhoc targets on diabetes/pre-diabetes prevention, without ignoring other predictive factors.

\section{RESULTS}

\section{Pre-diabetes prevalence in Indonesia}

Out of 24417 subjects, who run the OGTT procedures, we got 20249, who had data on their diabetes diagnose status. From 20249, we took those who passed the inclusion criteria as adults they were: the subjects $\geq$ 18 years, and the results were 18956 . The remaining 18956 was subdivided on the bases of diabetes diagnosis criteria as follows:

Table 1. Diagnosis criteria of research population

\begin{tabular}{lcc}
\hline Diagnosis criteria & Total (n) & Prevalence (\%) \\
\hline Diagnosed Diabetes (DDM) & 280 & $1.5 \%$ \\
Undiagnosed Diabetes (UDDM) & 778 & $4.1 \%$ \\
Impaired Fasting Glucose (IGT) & 1887 & $10.0 \%$ \\
Non-diabetes (normal) & 16011 & $84.5 \%$ \\
Total & 18956 & $100 \%$ \\
\hline
\end{tabular}

Prediabetes prevalence (Impaired Glucose Tolerance) for adults in Indonesia is $10.0 \%$. The figure shows a minor difference with the analysis conducted by Basic Health Research Team 2007. This happened because the age criteria used was different. Basic Health Research used 15 year as the age criteria. Meanwhile, using 18 year as the criteria in this study is more accurate, because 18 years is the age limit for people in Indonesia and worldwide to be called adult.

Prevalence shown by total diabetes is $5.6 \%$. That indicates that pre-diabetes prevalence is almost twice higher than that of diabetes. It complies with the studies made in foreign countries, such as AusDiab, Framingham, DREAM and STOP-NIDDM.

\section{The characteristics of pre-diabetes in Indonesia}

The characteristics of pre-diabetes carriers are classified on the bases of age, sex, occupation, socio-economic status, education level, access to health services and various other predictive factors and socio-demography. Table 2 shows characteristics of pre-diabetes carrier in Indonesia.

Table 2 illustrates that the majority of diabetes carriers in Indonesia are females (61.6\%) with their occupation as housewives $(27.3 \%)$. The unemployed are quite high $(14.8 \%)$. So it is with the subjects whose occupation are entrepreneurs or service providers $(20 \%)$. Seen on age bases, most of the pre-diabetes subjects are in an age range between $38-47$, with the trend towards the escalating the proportion, owing to age increase. Seen on socio-economical status basis, majority of pre-diabetes carriers come from high socio-economical status. While seen on education level basis, we can see the escalating of the proportion, owing to the increasing of the education level, although it is not staggering drastically. 
Table 2. Characteristics of pre-diabetes in Indonesia

\begin{tabular}{|c|c|c|c|c|c|}
\hline No & Characteristics & Category & Total & Percentage & $p$-value \\
\hline 1 & Sex & $\begin{array}{l}\text { Male } \\
\text { Female }\end{array}$ & $\begin{array}{l}725 \\
1162\end{array}$ & $\begin{array}{l}38.4 \% \\
61.6 \%\end{array}$ & 0.000 \\
\hline 2 & Age & $\begin{array}{l}18-27 \text { year-old } \\
28-37 \text { year-old } \\
38-47 \text { year-old } \\
48-57 \text { year-old } \\
\geq 58 \text { year-old }\end{array}$ & $\begin{array}{l}301 \\
345 \\
477 \\
350 \\
414\end{array}$ & $\begin{array}{l}16 \% \\
18.3 \% \\
25.3 \% \\
18.5 \% \\
21.9 \%\end{array}$ & 0.000 \\
\hline 3 & Education level & $\begin{array}{l}\text { Never went to school } \\
\text { No elementary certified } \\
\text { Finish elementary school } \\
\text { Finish junior high school } \\
\text { Finish senior high school } \\
\text { University/academy }\end{array}$ & $\begin{array}{l}152 \\
272 \\
452 \\
370 \\
488 \\
143\end{array}$ & $\begin{array}{l}8.1 \% \\
14.5 \% \\
24.1 \% \\
19.7 \% \\
26 \% \\
7.6 \%\end{array}$ & 0.000 \\
\hline 4 & Job & $\begin{array}{l}\text { Jobless } \\
\text { Student } \\
\text { Housewife } \\
\text { Soldier/TNI } \\
\text { Civil government employee/PNS } \\
\text { Private employee } \\
\text { Enterpreneur or service providers } \\
\text { Farmer } \\
\text { Fisherman } \\
\text { Labor } \\
\text { Others }\end{array}$ & $\begin{array}{l}278 \\
95 \\
513 \\
11 \\
141 \\
119 \\
376 \\
113 \\
11 \\
152 \\
68\end{array}$ & $\begin{array}{l}14.8 \% \\
5.1 \% \\
27.3 \% \\
0.6 \% \\
7.5 \% \\
6.3 \% \\
20 \% \\
6 \% \\
0.6 \% \\
8.1 \% \\
3.6 \%\end{array}$ & 0.000 \\
\hline 5 & Social economy status & $\begin{array}{l}\text { Low } \\
\text { High }\end{array}$ & $\begin{array}{l}698 \\
1189\end{array}$ & $\begin{array}{l}37.2 \% \\
62.8 \%\end{array}$ & 0.000 \\
\hline 6 & Access to health care & $\begin{array}{l}\text { Easy } \\
\text { Difficult }\end{array}$ & $\begin{array}{l}1840 \\
45\end{array}$ & $\begin{array}{l}97.6 \% \\
2.4 \%\end{array}$ & 0.540 \\
\hline 7 & Hypertension & $\begin{array}{l}\text { No } \\
\text { Yes }\end{array}$ & $\begin{array}{l}944 \\
921\end{array}$ & $\begin{array}{l}50.6 \% \\
49.4 \%\end{array}$ & 0.000 \\
\hline 8 & Obesity & $\begin{array}{l}\text { No } \\
\text { Yes }\end{array}$ & $\begin{array}{l}1251 \\
634\end{array}$ & $\begin{array}{l}66.4 \% \\
33.6 \%\end{array}$ & 0.000 \\
\hline 9 & Central obesity & $\begin{array}{l}\text { No } \\
\text { Yes }\end{array}$ & $\begin{array}{l}1103 \\
762\end{array}$ & $\begin{array}{l}59.1 \% \\
40.9 \%\end{array}$ & 0.000 \\
\hline 10 & Physical inactivity & $\begin{array}{l}\text { No } \\
\text { Yes }\end{array}$ & $\begin{array}{l}1372 \\
515\end{array}$ & $\begin{array}{l}72.7 \% \\
27.3 \%\end{array}$ & 0.000 \\
\hline 11 & High risk diet & $\begin{array}{l}\text { No } \\
\text { Yes }\end{array}$ & $\begin{array}{l}30 \\
1847\end{array}$ & $\begin{array}{l}1.6 \% \\
98.4 \%\end{array}$ & 0.809 \\
\hline 12 & Smoking habit & $\begin{array}{l}\text { Everyday } \\
\text { Sometimes } \\
\text { Ex-smoker } \\
\text { Never smoked }\end{array}$ & $\begin{array}{l}354 \\
91 \\
110 \\
1322\end{array}$ & $\begin{array}{l}18.9 \% \\
4.9 \% \\
5.9 \% \\
70.4 \%\end{array}$ & 0.000 \\
\hline
\end{tabular}

Several data about pre-diabetes risk factors which are obtained from the Basic Health Research 2007, such as: hypertension, central obesity, and obesity, indicates that the pre-diabetes carriers who did not dominantly have a hypertension history, carry obesity and central obesity. So it is with the risk factors such as physical inactivity and smoking habit, which are not owned by the majority of pre-diabetes carriers in Indonesia. As for characteristics of risky diet pattern and access to health services, there are no significant differences seen from statistical point of view. This happened due to a great deal of the respondents, have high risk diet patterns towards diabetes/pre-diabetes and have an easy access to health services.

\section{Ecology of pre-diabetes/diabetes study on Indonesian population}

Ecology study is a picture descriptively made of two or more aggregates to see the trend of disease, which is connected with the related factors, where its analytical unit is not individual but population. In correlation analysis concerning risk factors upon pre-diabetes, we make a fusion between subjects included in impaired glucose tolerance category (IGT) and diabetes, in order to leave out the bias to respondents, already included in diabetes category.

Analysis unit used to see the correlation between prediabetes or diabetes and several relevant risk factors. 


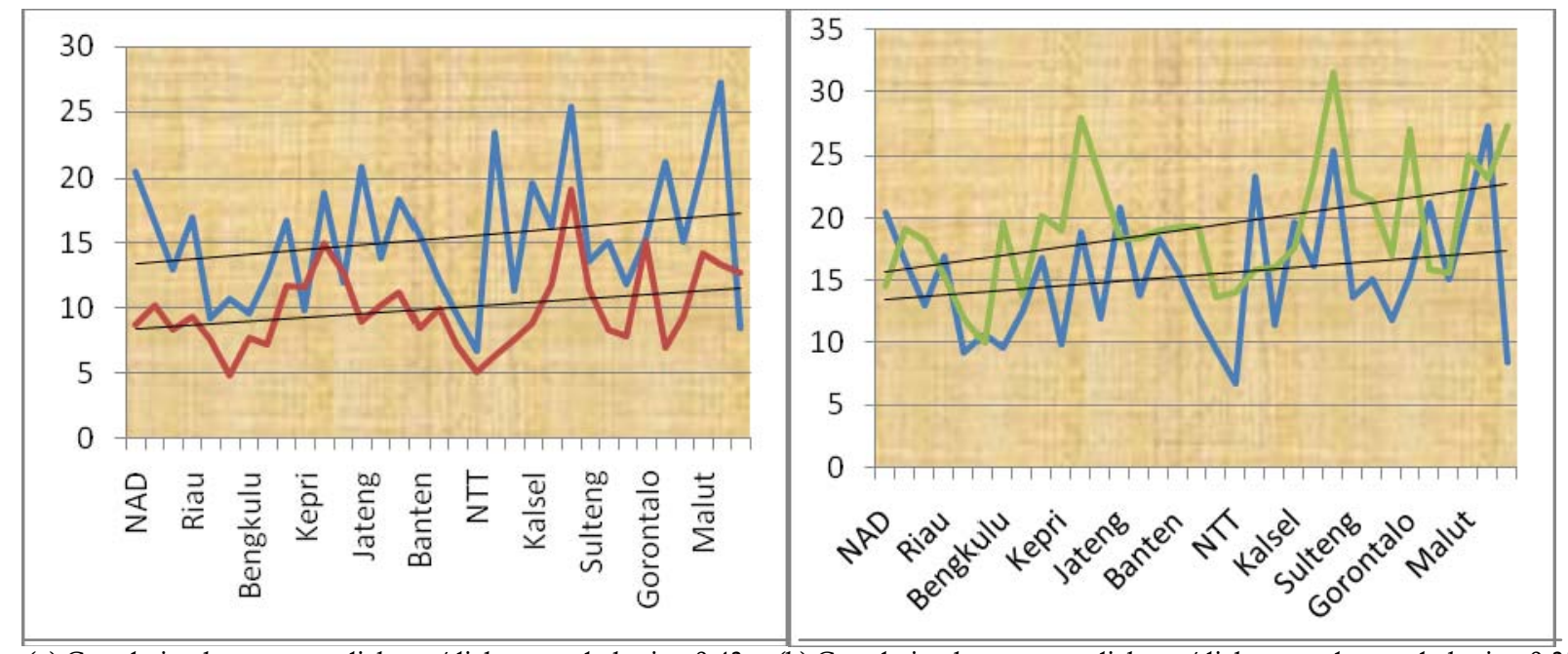

\begin{tabular}{ll}
\hline (a) Correlation between prediabetes/diabetes and obesity: 0.43 & (b) Correlation between prediabetes/diabetes and central obesity: 0.35
\end{tabular}

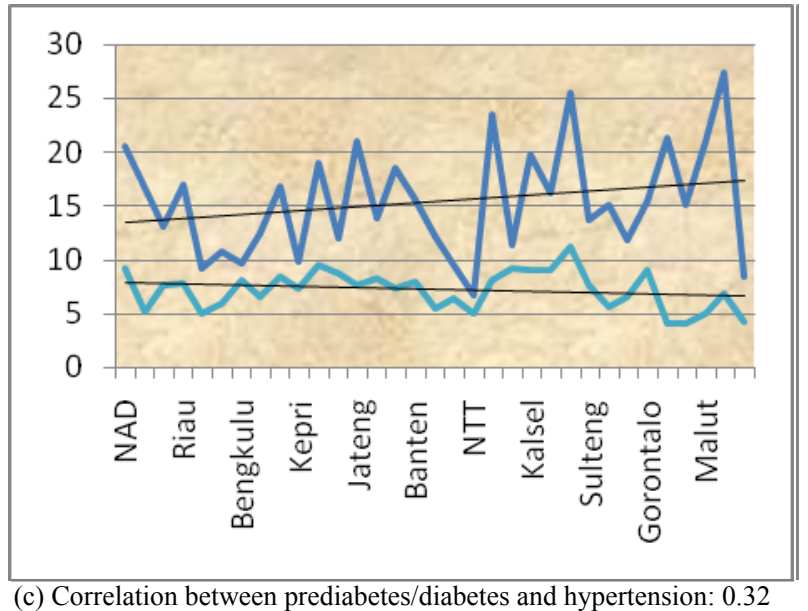

Notes: $\quad$ : Prevalence of prediabetes and diabetes in specific province

Other colour : Prevalence of predictive factors

Figure 1. Ecology analysis of prediabetes/diabetes subjects with the relevant predictive factors

Figure 1 shows several strong and positive correlations between pre-diabetes or diabetes and several risk factors.

Based on figure 1, we obtain that obesity, central obesity, hypertension, and high sweet diet have moderate correlation with prediabetes/diabetes in Indonesian population. This moderate correlation shows some focus of solutions in public health and population level. Based on ecology analysis on the population of every province, the trend of pre-diabetes or diabetes is increasing, together with the prevalence increase of obesity, central obesity and hypertension. The correlation shown by obesity is $0.43(\mathrm{r}=0.43)$, while for both obesity and hypertension, each with $\mathrm{r}$ of 0.35 and 0.32 , respectively. This correlation shows that there is a moderate-strong relation between hyperglycemia and obesity, central obesity and hypertension.

Correlation shown by hyperglycemia condition and several life styles such as, physical inactivity, greasy food consumption and sweet food consumption on the population of a province also indicates a positive and moderate - strong relation. Correlation shown by the several risk factors is population description of the people per province plainly; however, it gives illustration about a very good population trend, because it engages a large number of subjects.

Based on this analysis, we obtain a picture which reveals that pre-diabetes/diabetes has a significant relation with several risk factors statistically $(\mathrm{p}<0.05)$. 
Table 3. Correlation between several risk factors and prediabetes/diabetes in Indonesian population

\begin{tabular}{|c|c|c|c|c|c|c|c|}
\hline & & \multicolumn{4}{|c|}{ Category } & \multicolumn{2}{|c|}{ Total } \\
\hline & & \multicolumn{2}{|c|}{ Normal } & \multicolumn{2}{|c|}{$\begin{array}{c}\text { Prediabetes/ } \\
\text { Diabetes }\end{array}$} & \multirow[t]{2}{*}{$\mathbf{n}$} & \multirow[t]{2}{*}{ p-value } \\
\hline & & $\mathbf{N}$ & $\%$ & $\mathbf{n}$ & $\%$ & & \\
\hline \multirow[t]{2}{*}{ Sex } & Male & 7468 & $86.5 \%$ & 1150 & $13.5 \%$ & 8636 & \\
\hline & Female & 8525 & $82.6 \%$ & 1795 & $17.4 \%$ & 10320 & 0,000 \\
\hline \multirow[t]{5}{*}{ Age } & 18 - 27 year-old & 5206 & $93.5 \%$ & 361 & $6.5 \%$ & 5567 & \\
\hline & 28 - 37 year-old & 3870 & $89.4 \%$ & 461 & $10.6 \%$ & 4331 & \\
\hline & 38 - 47 year-old & 3235 & $81.7 \%$ & 726 & $18.3 \%$ & 3961 & 0,000 \\
\hline & 48 - 57 year-old & 2028 & $75.9 \%$ & 645 & $24.1 \%$ & 2673 & \\
\hline & $>58$ year-old & 1672 & $69 \%$ & 752 & $31 \%$ & 2424 & \\
\hline \multirow{2}{*}{$\begin{array}{l}\text { Social economy } \\
\text { status }\end{array}$} & High & 9730 & $83.6 \%$ & 1908 & $16.4 \%$ & 11638 & 0,000 \\
\hline & Low & 6281 & $85.8 \%$ & 1037 & $14.2 \%$ & 7318 & \\
\hline \multirow{2}{*}{ Education } & High & 6132 & $86.1 \%$ & 994 & $13.9 \%$ & 7126 & 0,000 \\
\hline & Low & 9763 & $83.4 \%$ & 1939 & $16.6 \%$ & 11702 & \\
\hline \multirow[t]{2}{*}{ Hypertension } & No & 10830 & $88.9 \%$ & 1348 & $11.1 \%$ & 12178 & 0,000 \\
\hline & Yes & 4932 & $75.9 \%$ & 1570 & $24.1 \%$ & 6502 & \\
\hline \multirow[t]{2}{*}{ High risk diet } & No & 15597 & $84.4 \%$ & 2884 & $15.6 \%$ & 18481 & 0,701 \\
\hline & Yes & 298 & $85.9 \%$ & 49 & $14.1 \%$ & 347 & \\
\hline \multirow[t]{4}{*}{ Smoking habit } & Everyday & 3987 & $88.4 \%$ & 525 & $11.6 \%$ & 4512 & \\
\hline & Sometimes & 959 & $87.5 \%$ & 137 & $12.5 \%$ & 1096 & 0,000 \\
\hline & Ex-smokers & 669 & $77.6 \%$ & 193 & $22.4 \%$ & 862 & \\
\hline & Never smoked & 10280 & $83.2 \%$ & 2078 & $16.8 \%$ & 12358 & \\
\hline \multirow[t]{2}{*}{ Access to health care } & Easy & 15521 & $84.4 \%$ & 2870 & $15.6 \%$ & 18391 & 0,340 \\
\hline & Difficult & 490 & $93.9 \%$ & 69 & $6.1 \%$ & 522 & \\
\hline \multirow[t]{2}{*}{ Central obesity } & No & 11517 & $87.7 \%$ & 1617 & $12.3 \%$ & 13134 & 0,000 \\
\hline & Yes & 4245 & $76.5 \%$ & 1301 & $23.5 \%$ & 5546 & \\
\hline \multirow[t]{2}{*}{ Obesity } & No & 12446 & $87 \%$ & 1866 & $13 \%$ & 14312 & 0,000 \\
\hline & Yes & 3556 & $76.8 \%$ & 1077 & $23.2 \%$ & 4633 & \\
\hline \multirow[t]{2}{*}{ Physical inactivity } & No & 12091 & $85.1 \%$ & 2116 & $14.9 \%$ & 14207 & 0,000 \\
\hline & Yes & 3920 & $4.7 \%$ & 829 & $95.3 \%$ & 4749 & \\
\hline
\end{tabular}

Two variables, which do not shows any significant relation statistically with pre-diabetes/diabetes are access to health service $(\mathrm{p}=0.340)$ and risky diet pattern $(p=0.701)$. It happened because access proportion to health service is easy and risky diet pattern is very high in the circle of respondents (proportion $>95 \%$ ).

\section{Pre-diabetes multivariate analysis on Indonesian people}

In the framework of acquiring pre-diabetes predictive factors on Indonesian people, we created a multivariate analysis by way of controlling method upon other variables in an epidemiological model by means of multivariate analysis, we can get OR (ratio odds) value, which gives information about relative opportunity value of an incidence (in this case pre-diabetes), based on available / unavailable of those predictive factors (for instance: socio-demographical characteristics, life style, or relevant comorbidity) on the relevant subjects. Variables that eligible for multivariate test are variables, which give significant value statistically on bivariate analysis $\mathrm{P}<0.25$.

Based on the multivariate analysis, we obtain several predictive factors related with pre-diabetes/diabetes spectrum in Indonesia. Some of the predictive factors, which belong to the unchangeable factors, are male sex and old age. While factors related to comorbidity and life style are hypertension, obesity, central obesity, and smoking habit. Two socio-demographical factors which belong to pre-diabetes/diabetes predictor are high socio-economical status and low education level. These predictive factors are identical with diabetes mellitus predictive factors (without engaging pre-diabetes subjects) in the study conducted by Pramono et al..$^{13}$, however, it differs with the study conducted by Mihardja et al. ${ }^{14}$, owing to the different criteria used in several variables. 
Table 4. Predictors analysis of prediabetes/diabetes in Indonesian population

\begin{tabular}{|c|c|c|c|c|}
\hline Variable & Category & OR & $95 \%$ CI & p value \\
\hline \multirow[t]{2}{*}{ Sex } & Male & & & \\
\hline & Female & 0.8 & $0.61-0.92$ & 0.020 \\
\hline \multirow[t]{5}{*}{ Age } & $18-27$ year-old & & & \\
\hline & 28-37 year-old & 1.9 & $1.42-2.91$ & 0.000 \\
\hline & $38-47$ year-old & 4.8 & $3.32-6.83$ & 0.000 \\
\hline & 48-57 year-old & 8.7 & $7.8-9.2$ & 0.000 \\
\hline & $\geq 58$ year-old & 11.2 & $9.9-12.6$ & 0.000 \\
\hline \multirow[t]{2}{*}{ Social economy status } & Low & & & \\
\hline & High & 1.1 & $1.04-1.21$ & 0.030 \\
\hline \multirow[t]{2}{*}{ Education level } & High & & & \\
\hline & Low & 1.2 & $1.04-1.40$ & 0.010 \\
\hline \multirow[t]{2}{*}{ Hypertension } & No & & & \\
\hline & Yes & 1.4 & $1.22-1.74$ & 0.000 \\
\hline \multirow[t]{2}{*}{ Obesity } & No & & & \\
\hline & Yes & 1.2 & $1.12-1.53$ & 0.000 \\
\hline \multirow[t]{2}{*}{ Central obesity } & No & & & \\
\hline & Yes & 1.5 & $1.36-1.78$ & 0.000 \\
\hline \multirow[t]{2}{*}{ Smoking habit } & Smokers & & & \\
\hline & Non-smokers & 1.4 & $1.22-1.68$ & 0.000 \\
\hline
\end{tabular}

Particularly for smoking habits, the analysis shows paradoxical results against general theory, and the studies developed up till now. In this study we discover that "non-smokers' (combination between ex-smokers and non smokers) increases the pre-diabetes/diabetes prediction, compared to "smoker subjects' (combination between daily smokers and once in a while smoker). Some other candidates such as access to health service, risky diet pattern, and physical inactivity do not give significance statistically, so that they do not belong to pre-diabetes/diabetes predictive factors in Indonesia.

\section{Attributable risk of predictive factors of pre- diabetes in Indonesia}

Attributable risk is used to measure how big the size of community health problem (question), resulted from exposure or predictive factor. This evaluation is coming in useful for determining the priority on public health action in a certain sub-district area, a province, or a country. In the measuring of pre-diabetes, we use impact parameter AR \% (attributable risk percent), that is, the decrease percentage of the size of health problems (prediabetes prevalence), when predictive factor is left out. Table 5 shows the list of pre-diabetes AR\% on several predictive factors that can be prevented.

Based on AR\% shown on Table 5, we can see that hypertension has the highest impact to pre-diabetes/ diabetes in Indonesia. AR\% as big as $56.5 \%$ indicates that if hypertension predictive factor merely is left out, pre-diabetes/diabetes incidences in Indonesia can be lowered $56.5 \%$ of existing prevalence Thereby, lowering the blood pressure will give the greatest prevalence decrease compared to preventing other factors. In the domain of public health action, hypertension prevention suppose to become priorit in policy or adhoc target (adhoc achievements) in socialization programs, without ignoring certain other predictive factors.

\section{DISCUSSION}

\section{Prevalence and characteristics of pre-diabetes in Indonesia}

Pre-diabetes prevalence on adult people in Indonesia is $10.0 \%$. This computation merely engages subjects aging $\geq 18$ year. The age limit complies with the age limit for adults, which is acknowledged both in health and law fields in Indonesia. This figure occupies almost two-fold of diabetes mellitus prevalence in Indonesia (5.6\%). Almost similar condition can be found on several studies like in Singapore, where prediabetes $(15 \%)$ gets prevalence higher than diabetes $(9 \%) .{ }^{5}$ And what is more, in Africa region by and large, pre-diabetes prevalence is twice $(7.1 \%)$ than that of diabetes prevalence $(3.2 \%){ }^{15}$ 
Table 5. Attributable risk of several predictive factors of prediabetes in Indonesia

\begin{tabular}{|c|c|c|}
\hline Predictive factors & AR\% & Notes \\
\hline Obesity & $23 \%$ & \\
\hline Central obesity & $47.3 \%$ & \\
\hline Hypertension & $56.5 \%$ & Priority for public health action \\
\hline Physical inactivity & $23 \%$ & \\
\hline $\begin{array}{l}\text { High risk diet (less } \\
\text { fruits and vegetables) }\end{array}$ & $16.7 \%$ & \\
\hline No smoking habit & $44.4 \%$ & $\begin{array}{l}\text { Contrary with biological } \\
\text { plausibility and most } \\
\text { epidemiological studies, no } \\
\text { smoking habit in this study is a } \\
\text { risk factor for pre-diabetes }\end{array}$ \\
\hline
\end{tabular}

Nevertheless, the different conditions are found in some other countries. The study, conducted by Mohan et al. ${ }^{16}$ in India, discovered that the prevalence of diabetes and IGT in urban areas in India is $15.5 \%$ and $10.6 \%$. Meanwhile, the study of Al-Nozha et a ${ }^{17}$ discovered that diabetes prevalence and Impaired Fasting Glucose (IFG) in Arab-Saudi is $23.7 \%$ and $14.1 \%$. Both showed that IFG prevalence was lower than diabetes prevalence.

Data shown from the present study, Mohan and AlNoza had weakness on pre-diabetes data, while this study and Mohan's. have no IFG data, meanwhile the study of Al-Nozha's. did not take IGT data. It is different with the study of AusDiab in Australia, who had pre-diabetes data, derived from the combination of IGT and IFG, that is $10.6 \%$ and $5.8 \%$ respectively, so that they obtained data for pre-diabetes prevalence $16.4 \%$. The establishment of diabetes and pre-diabetes diagnoses applied merely one measurement (Impaired Fasting Glucose only, or just two hour post glucose load) could underestimate the prevalence of diabetes and pre-diabetes. ${ }^{18}$ The addition of IGT and IFG, gave a more complete illustration about pre-diabetes prevalence in a certain areas.

Apart from the completeness of pre-diabetes data, which is merely shown by IGT, this study also has limitation, which is the sample collection technique. In the Basic Health Research 2007, at the test stage, where blood glucose levels was examined, the respondents included were derived merely from urban residents, with the result that could not produce a comprehensive prevalence for pre-diabetes prevalence in Indonesia. Unfortunately, blood glucose level test for diabetes diagnoses is still difficult to be conducted in the areas. Up till now, there are still limited number of community epidemiology studies in Indonesian rural areas, and a considerable part of them are done merely locally, for instance: in rural area in Bali made by Suastika, and Ende Diabetes Study made by Waspadji et al. ${ }^{19}$
Other weakness which is significant enough is the lack of diabetes historical data in the family, on the predictive factor candidates. This is because Basic Health Research Team did not put the variable mentioned, at the time of making the questioner form. This matter should be evaluated in the future, by the way of socialization, recommendations and the mentioning of the variable: diabetes history in family, in coming national surveys.

The strength of this study is that the research data covers nationwide, collected from 33 provinces across Indonesia. The research data of this big-scale, could only be obtained by a nation-wide survey, coordinated by Health Ministry, Republic of Indonesia. In terms of the data newness, Basic Health Research 2007 is the last nation-wide health survey conducted in Indonesia. Thereby, the data obtained are current data. Apart from that, compared with the study conducted by Mihardja et al. ${ }^{14}$ the results obtained put more weight on illustrating the prevalence of real adult person, owing to the applying of age standard $\geq 18$ year.

Pre-diabetes prevalence obtained in this study illustrate that one of ten people in Indonesia goes through the impaired glucose tolerance. If there is no intervention or adequate and appropriate secondary prevention, this condition will lead him/her to be affected by diabetes. The progressivity of IGT to become diabetes is $6-10 \%$ per year. ${ }^{7}$ Besides, IGT carrier generally, has a bad lipid profile according to the criteria, stipulated by National Cholesterol Education Program (NCEP). The conditions caused IGT victims to get the administration, both non--pharmacologically and pharmacologically.

Pre-diabetes carrier in Indonesia is dominated by woman $(61.6 \%$, mostly with the age range of $38-47$ year $(25.3 \%)$, followed by elderly ( $\geq 58$ year) with trend of soaring, owing to the age increase. This discovery complies with the diabetes epidemiological profile world-wide, discovered by Wild et al. ${ }^{20}$ Globally, on the age under 60 years, diabetes prevalence on males is higher that on females, however, on the age above 60 years, the figure changes. By large, diabetes proportion in the world is higher on females than males. Most possibly this is caused by the number as well the life expectation figure of the females, are higher than males.

In the developed countries, more of the diabetes carriers are in the age range of above 65 years, compared to people in the younger age range. In the developing countries the conditions occurred are the other way round. The prevalence of diabetes carriers in developed countries lies more on the range of ages 45-64 years. On the age of young adults, the prevalence is higher than average prevalence of diabetes of young adults worldwide..$^{20}$ This indicates that the transition of economy, 
socio-culture, and epidemiology in the developing countries, have caused the increasing of prevalence of degenerative diseases and life styles such as diabetes in the more and more younger ages.

The study related to sex and age (adjusted) is required in the diabetes epidemiology studies. The reason is because each sex and age levels have a different risk factors. The DECODA Study ${ }^{18}$ discovered that there is a conspicuous difference on the prevalence of diabetes and Impaired Glucose Tolerance, on various races, ages, and sexes in 11 Asian countries. Prevalence of diabetes is increasing owing to age but with the peak prevalence, which is different between races. ${ }^{18}$ Data which has a specific in age and sex, will give a more complete comprehension to diabetes on every group. The case aforementioned, aimed to improve the efficiency of prevention strategy on each group. In the future, diabetes epidemiology studies in Indonesia will be directed to the specific age and sex.

\section{Pre-diabetes predictive factors in Indonesia}

There are several ways to do an epidemiology analysis on data obtained by means of survey. Some methods that can be used are ecology study, bivariate and multivariate analysis, and impact/effect analysis. This study produces various analyses, so that it is expected that this study can give a complete picture on risk factors and pre-diabetes prediction in Indonesia.

Ecology study is a descriptive method, which shows correlation between bound variables (diseases) and free variables (risk factors), with analysis unit as population. Population used in this study is the people who live in a certain province. In this study, it is discovered that there is a moderate - strong correlation on some risk factors in a certain population, among others: obesity $(\mathrm{r}=0.43)$, central obesity $(\mathrm{r}=0.35)$, hypertension $(\mathrm{r}=0.32)$, physical inactivity $(\mathrm{r}=0.21)$, greasy food consumption $(\mathrm{r}=0.22)$, and sweet food consumption $(\mathrm{r}=0.39)$. For a study which engages subjects in a gigantic amount of people on a national scale, the correlation value mentioned, shows a real relation between pre-diabetes/ diabetes trend in a certain area, and comorbidity and life style trend in a certain province.

Based on the bivariate and multivariate analysis, we discover several pre-diabetes predictive factors on Indonesian people, they are: sex, age, socialeconomic status, education level, obesity, central obesity, hypertension, and no smoking habit. These predictive factors differ from the findings of Mihardja et al. ${ }^{14}$, where Mihardja got age, sort of occupation, hypertension, central obesity, obesity, and smoking habit as determinant factors (multivariate) on prediabetes/diabetes. This happens due to the variable selection and criteria establishment are different with that of Mihardja's.

Mihardja subdivided smoking habit into: smoking 1-24 cigarette/day and smoking $\geq 25$ cigarettes/day. This makes OR 1.7, with smoking risk $\geq 25$ cigarettes /day, which is higher than smoking group 1-24.cigarette/day. Although the subdivision may cause bias to occur, on measuring (subject smokes 1 cigarette / day), however the conclusion obtained is better than this study. By subdividing into smoking and non-smoking, this study precisely discover that smoking become a protective factor for pre-diabetes, something which still need a further explanation and cannot be absorbed utterly. Actually, this findings has the same results as Pramono et $\mathrm{al}^{13} \mathrm{~s}^{13}$ in Indonesian undiagnosed diabetes subjects. This phenomenon should be studied in the future projects.

Although we obtain a similar conclusion concerning age risk factor with Mihardja et al., this study has a detailed division in age, by dividing into ranges of 10 years, so that the picture of epidemiology and risk can be seen more clearly, between the young adults, the adults and the elders. This study got an increase in OR compatible with the increment of age span. Meanwhile, males were predicted to carry pre-diabetes/diabetes higher than female sex. This finding is similar with the study of Franse et al. ${ }^{21}$, who discovered that males runs the risk to carry diabetes higher than female sex.

Obesity, central obesity, and hypertension increase the pre-diabetes/diabetes prediction in OR, each was 1.2 (95\% CI 1.12-1.53), 1.5 (95\% CI 1.36-1.78), and 1.4 (95\% CI 1.22-1.74). While high socio-economical status and low education level increase the pre-diabetes/ diabetes prediction. This happened because in the high socio-economic status, the opportunity of the sedentary lifestyle is bigger, while in low education level, the subject has a lack of knowledge about pre-diabetes/ diabetes prevention.

\section{Indonesian Diabetes Prevention Program}

One of the strategies, which is already socialized in some foreign country's health organizations, particularly diabetes organization, to constrain prediabetes development to become diabetes is Diabetes Prevention Program (with acronym DPP). DPP has two objectives, which is subdivided into primary and secondary objectives. DPP's primary objective is to prevent or to decelerate diabetes development on IGT subjects. While DPP's secondary objective is to decrease incidences of cardio-vascular, the risk of cardio-vascular complication, and to prevent atherosclerosis. ${ }^{22}$

DPP has been in operation in several countries worldwide. Some national-scale clinical studies are conducted 
to measure DPP's achievements in constraining the progressivity of pre-diabetes to become diabetes. Two of DPP's strategies, extensively applied, are life style changes, by way of doing physical activities regularly at least 150 minutes a week and diet to get a decrease of $7 \%$ of body weight, and the using of metformin 850 mg two times per day. ${ }^{21}$ In The United States, by just changing the life styles only, the people can decrease on average $58 \%$ the risk to be become diabetes. The lifestyle changes are extremely influential on the age group above 60 years (decrease progressivity to become diabetes $71 \%$ ). After a year's observation period, the subjects who become diabetes in the treatment group (make changes in life style) is $5 \%$, which is far lower than control group $11 \%$. While just metformin only, is able to decrease the progressivity of pre-diabetes to become diabetes $31 \%$ and it is most effective on the young adults (25-44 year).

The study conducted by Orchard et al. ${ }^{23}$ conclude that life style changes and the using of metformin decrease the incidence of metabolic syndrome on IGT subjects. Just life style changes only, decrease the incidence of metabolic syndrome $41 \%$ and the using of metformin decrease the incidence $17 \%$. In Canada, the success of DPP needs to be supported by a very effective health promotion since school age. According to Ho et al. except for life style changes and pharmacotherapy, DPP need to be supported by a good socialization system, the accessibility of health services, and a good perception of the community to the diabetes prevention. ${ }^{24}$

In Asian region, India included as one of the countries, which has run clinical study of DPP in a national-scale. The study conducted by Ramachandran et al. obtained that life style changes and metformin can prevent diabetes on the subjects, who have already diagnosed as IGT. ${ }^{25}$ The Relative Risk Reduction (RRR) on life style changes is $28.5 \%$, the using of metformin $26.4 \%$, and the combination of the two is $28.2 \%$ This indicates that whether life style changes or the using of metformin, both are equally important in decreasing the incidence of diabetes.

Up to this moment, In Indonesia, we have no clinical study in national scale to the efficacy of DPP in preventing and decelerating the pre-diabetes to become diabetes. The studies related to the life style changes, diet, education and health promotion, along with pharmaceutical products, needs to be made in order to know which of the DPP's strategies, that is the most agreeable to Indonesian people. Nevertheless, based on the impact analysis of predictive factors on prediabetes discovered on this study, the researchers can aim to targets for life style changes, health promotion, and the using of the pharmaceutical products mentioned on some priorities or adhoc targets, they are : the decreasing of blood pressure, central obesity, and stop smoking.

Based on the impact/effect analysis of pre-diabetes/ diabetes, if all subjects decrease their blood pressure to normal level, pre-diabetes/diabetes could be decreased to $56.5 \%$, and so do the waistline, If they can shorten the waistline to normal level and stop smoking, in which case each of them can decrease the incidence of prediabetes/diabetes to $47.3 \%$ and $44.4 \%$. This measuring of impact (AR\%) will be very useful to set the policy and clinical recommendation to determine the priority of targets to be achieved. By setting some adhoc targets, like: the decreasing of blood pressure, the shortening of waistline, and stop smoking aforementioned, anyone can more clearly knows just what kind of behavior exactly, that should be done and what variable to be checked to the medical care experts.

Indonesian Diabetes Prevention Program (IDPP) is a discourse, that should be discussed, either on the clinicians levels, professional organizations, or interesting parties (Indonesian Society for Endocrinologist, Indonesian Diabetes Association, and Indonesian Diabetes Educator Association), along with the Government (Health Department RI), so that all parties cooperate in arranging (1) clinical studies to have a knowledge of the efficacy of IDPP, (2) a system, that can support the success of IDPP, (3) recommendation to IDPP, (4) Socialization strategy, and (5) evaluation to the achievements of IDPP (either locally or nationally). It is really hoped that through a series of these program in the near future, Indonesia will be able to decrease the prevalence of pre-diabetes and diabetes in such a way that spoilage level, death, along with medication costs as the result from both diseases can be reduced

In conclusion, pre-diabetes prevalence based on IGT data in Indonesia is $10 \%$. The figure was almost two-fold of diabetes prevalence, that is, 5.6\%. A considerable part of pre-diabetes carriers in Indonesia are females. Span of age that mostly affected, is 3847 year. Based on the inter-provinces ecology study in Indonesia, it is found that pre-diabetes has a moderate - strong and positive correlation with obesity, central obesity, hypertension, physical inactivity, greasy food consumption, sweet food consumption.

Pre-diabetes predictive factors in Indonesia are male sex, old age, high socio-economical status, low education level, obesity, central obesity, and hypertension. Based on impact parameter analysis, priority of the prevention of pre-diabetes/diabetes in Indonesia, ought to be directed consecutively to the decreasing of blood pressure, the prevention of central obesity, and stop smoking. Furthermore, the prevention of obesity and 
physical activity also need to get attention, to prevent pre-diabetes condition and the development of prediabetes from becoming diabetes in the people across Indonesia.

The implementation of the several strategies can be summarized and socialized in Indonesian Diabetes Prevention Program (IDPP). The implementation of IDPP starts from clinical study stage, recommendation, socialization, up to achievements evaluation should be carried out by team consisting of clinicians, professional organization and interesting parties, along with the Government (Health Department RI). It is expected that IDPP will be able to become an appropriate and adequate national strategy, to decrease the pandemic of diabetes and pre-diabetes in Indonesia.

\section{Acknowledgments}

We thank to The Institute of Research and Health Development, Ministry of Health Republic of Indonesia, for without their help, this study would not have been possible. Further thanks are given to The Center of Biomedical and Pharmacy and along with it to Basic Health Research Team 2007 for their generosity in allowing us to access their data. Thanks also to all staffs of Division of Metabolic Endocrinology, Department of Internal Medicine FMUI/RSCM and The Jakarta Center of Diabetes and Lipid for their cooperation during the processing of data of this study. This study would not have been possible without the help of those parties mentioned above.

\section{REFERENCES}

1. US Department of Health and Human Services, American Diabetes Association. HHS, ADA warn Americans of "prediabetes". Washington, DC: DHHS, 2002.

2. Garber AJ, Handelsman Y, Einhorn D, Bergman DA, Bloomgarden Z, Fonseca V, etal. Diagnosis and Management of Prediabetes in the Continuum of Hyperglycemia-When Do the Risks of Diabetes Begin? A Consensus Statement from the American College of Endocrinology and the American Association of Clinical Endocrinologists. Endocr Pract. 2008;14(7):933-46.

3. Bennet PH, Knowler WC. Definition, diagnosis, and classification of diabetes mellitus and glucose homeostasis. In Khan CR, King GL, Moses AC, Weir GC, Jacobson AM, Smith RJ, editors. Joslin's Diabetes Mellitus. Boston; Lippincott Williams and Wilkins, 2005.

4. Lim JG, Kang HJ, Stewart KJ. Type 2 diabetes in Singapore: the role of exercise training for its prevention and management. Singapore Med J. 2004;45(2):62-8.

5. Twigg SM, Kamp MC, Davis TM, Neylon EK, Flack JR. Prediabetes: a position statement from the Australian Diabetes Society and Australian Diabetes Educators Association. Med J Aust. 2007;186(9):461-5.
6. Yunir E. Prevalensi pre-diabetes pada populasi umum berusia 25-64 tahun di lima wilayah DKI Jakarta. Hasil penelitian disampaikan pada Gelar Hasil Penelitian Ilmu Penyakit Dalam, Hasil Penelitian Surveilans Beberapa Penyakit Perkotaan di Lima Wilayah DKI Jakarta tahun 2006, Jakarta, 2006.

7. de Vegt F, Dekker JM, Jager A, et al. Relation of impaired fasting and postload glucose with incident type 2 diabetes in a Dutch population: the Hoorn Study. JAMA. 2001;285:2109-13.

8. ESC and EASC Guidelines. Guidelines on diabetes, prediabetes, and cardiovascular diseases. Eur Heart J. 2007; 9 (Supplement C), C3-C74.

9. Kenealy T, Elley CR, Arrol B. Screening for diabetes and prediabetes. Lancet. 2007;370(8):1888-9.

10. Kanazawa M, Yoshiike N, Osaka T, Numba Y, Zimmet P, Inoue S. Criteria and classification of obesity in Japan and Asia-Oceania. World Rev Nutr Diet. 2005;94:1-12.

11. McNeely MJ, Boyko EJ, Shofer JB, Morris LN, Leonetti DL, Fujimoto WY. Standard definitions of overweight and central adiposity for determining diabetes risk in Japanese Americans. Am J Clin Nutr. 2001;74(1):101-7.

12. Chobanian AV, Bakris GL, Black HR, Cushman WC, Green LA, Izzo JL, Jones DW, et al. The seven report of the Joint National Committee on Prevention, Detection, Evaluation, and Treatment of High Blood Pressure. JAMA. 2003;289(19):2560-72.

13. Pramono LA, Setiati S, Soewondo P, Subekti I, Adisasmita A, Kodim N, Sutrisna B. Prevalence and predictors of undiagnosed diabetes melitus in Indonesia. Acta Med Indones. 2010;42(4):216-23.

14. Mihardja L, Delima, Siswoyo H, Ghani L, Soegondo S. Prevalence and determinants of diabetes mellitus and impaired glucose tolerance in Indonesia. Acta Med Indones. 2007;41(4):169-74.

15. Mbanya JC. Type 2 diabetes mellitus: descriptive epidemiology. IDEC Training Course, 2006.

16. Mohan V, Deepa M, Deepa R, Shanthirani CS, Farooq S, Ganesan A, Datta M. Secular trends in the prevalence of diabetes and impaired glucose tolerance in urban South India - the Chennai Urban Rural Epidemiology Study (CURES-17). Diabetologia. 2006;49:1175-8.

17. Al-Nozha MM, Al-Maatouq MA, Al-Mazrou YY, Al-Harthi SS, Arafah MR, Khalil MZ, et al. Diabetes mellitus in Saudi Arabia. Saudi Med J. 2004;25(11):1603-10.

18. The DECODA Study Group. Age and sex specific prevalence of diabetes and impaired glucose regulation in 11 Asian cohorts. Diab Care. 2003;26(6):1770-80.

19. Waspadji S, Soewondo P, Subekti I, Soebardi S, Harbuwono DS, Pramono LA, Supali T. Diabetes in Indonesian rural area - Ende Diabetes Study: prevalence of diabetes and community knowledge in Nangapanda, Ende District, East Nusa Tenggara. Publication in process.

20. Wild S, Roglic R, Green A, Sicree R, King H. Global prevalence of diabetes. Diab Care. 2004;27(5):1047-53.

21. Franse LV, Bari MD, Shorr RI, Resnick HE, Van Eijk JTM, Bauer DC, Newman AB. Type 2 diabetes in older well-functioning people: who is undiagnosed? Diab Care. 2001;24:2065-2070.

22. The Diabetes Prevention Program Research Group. The diabetes prevention program. Diabetes Care 2000;23(11):1619-29.

23. Orchard TJ, Temprosa M, Goldberg R, Haffner S, Ratner R, Marcovina $\mathrm{S}$, et al. The effect of metformin and intensive 
lifestyle intervention on the metabolic syndrome: the diabetes prevention program randomized trial. Ann Intern Med. 2005;142:611-9.

24. Ho LS, Gittelsohn J, Harris SB, Ford E. Development of an integrated diabetes prevention program with First Nations in Canada. Health Prom Int. 2006;21(2):88-97.
25. Ramachandran A, Snehalatha C, Mary S, Mukesh B, Bhaskar AD, Vijay V. The Indian Diabetes Prevention Program shows that lifestyle modification and metformin prevent type 2 diabetes in Asian Indian subjects with impaired glucose tolerance (IDPP-1). Diabetologia. 2006;49:289-97. 